\title{
MANAJEMEN PELAYANAN HAJI DAN UMROH DI KEMENTERIAN AGAMA KABUPATEN MOJOKERTO
}

\author{
Mukti Ali, Nurul Wahidatul M, Wilis Ayu, Dea Fajar, Ni'matus \\ Sholihah \\ UIN Sunan Ampel, Surabaya - Indonesia | qmr.majidah25@gmail.com
}

\begin{abstract}
Abstrak: Penelitian ini bertujuan untuk mengetahui dan mendeskripsian tentang manajemen pelayanan haji dan umroh di kementerian agama kabupaten Mojokerto. Metode penelitian yang digunakan adalah penelitian kualitatif. Teknik pengumpulan data menggunakan wawancara, observasi dan dokumentasi dengan informan yaitu pengelola bagian penyelenggaraan haji dan umroh dan petugas PHU. Hasil penelitian menunjukkan bahwa bagian penyelenggaraan $\mathrm{Haji}$ dan Umrah Kantor Kementerian Agama Kabupaten Mojokerto memiliki sebuah pelayanan yang dapat memudahkan jama'ah untuk melakukan pendaftaran yakni pelayanan satu atap yang berdiri pada tahun 2016 Pada awalnya, fungsi secara umum dari pelayanan haji dan umrah adalah untuk meningkatkan pelayanan dan penyelenggaraan ibadah haji dan umrah. Setelah dilakukan penelitian ini, dapat disimpulkan bahwa dengan adanya manajemen pelayanan haji dan umroh, kegiatan atau aktivitas dalam layanan bisa terkoordinir atau terstruktur dengan baik, sehingga calon jamaah haji dan umroh merasa nyaman.
\end{abstract}

Keywords: manajemen, pelayanan

\section{Pemdahuluan}

Penyelenggaraan ibadah haji merupakan amanat UU No. 13 tahun 2008 tentang penyelenggaraan ibadah haji. Sesuai peraturan perundang-undangan tersebut, penyelenggaraan ibadah haji ini menjadi tanggungjawab pemerintah yang dikoordinasikan oleh Menteri Agama RI. Hal tersebut setelah dipertimbangkan kembali bahwa penyelenggaraan ibadah haji ini adalah tugas nasional dan 
menyangkut martabat serta nama baik bangsa.1Berdasarkan undang-undang tersebut maka dibutuhkan suatu manajemen yang baik guna mensukseskan penyelenggaraan ibadah haji.2Manajemen memiliki fungsi-fungsi dan unsur-unsur didalamnya, yang apabila fungsi-fungsi dan unsur-unsur manajemen jika dijalankan dengan baik maka akan menghasilkan output dan outcome yang baik juga.Pelaksanaan manajemen ibadah haji yang efektif dan efisien menuntut terlaksananya keempat fungsi utama manajemen tersebut secara terpadu dan terintegrasi dalam pengelolaan bidang-bidang kegiatan manajemen ibadah haji dan umroh.

Pelayanan penyelenggaraan ibadah haji yang di lakukan oleh Kementerian Agama tidak terlepas dari berbagai problematika atau masalah, khususnya pada tahun 2015. Berbagai masalah sering dihadapi oleh Kementerian Agama dalam memberikan suatu pelayanan di bidang administrasi dokumen, keuangan, bimbingan jama'ah, transportasi, kesehatan, akomodasi, katering, dan keamanan atau perlindungan kepada calon jama;ah haji. Persoalan dalam proses pendaftaran calon jama'ah haji. Pendaftaran calon jama'ah haji dilakukan setiap tahun oleh kantor Kementerian Agama kabupaten Mojokerto sendiri tanpa adanyabatasan kuota haji nasional. Warga negara Indonesia berhak atau mempunyai hak untuk melaksanakan ibadah haji yaitu dengan mendaftarkan dirinya di kantor Kementerian Agama kabupaten Mojokerto sesuai dengan prosedur atau tata carayang ada dan persyaratan yang ditetapkan oleh Kementerian Agama kabupaten Mojokerto. Dalam melayani pendaftaran calon jama'ah haji Kementerian Agama kabupaten Mojokerto mengalami beberapa persoalan diantaranya yaitu terdapat ketidakseimbangan dokumen identitas diri calon jam'ahhaji antara dokumen pendukung jamaah berupa surat nikah atau ijazah dengan dokumen utama calon jama'ah haji berupa kartu

${ }^{1}$ Imam Syaukani (Ed.), Kepuasan Jemaah Haji Terhadap Kualitas Penyelenggaraan Ibadah Haji Tahun 1430 H/2009 M, (Jakarta: Puslitbang Kehidupan Keagamaan Badan Litbang dan Diklat Kementrian Agama RI, 2011), hlm. 1.

${ }^{2}$ Ernie Tisnawati Sulekurniawa dan Kurniawan Saefullah, Pengantar Manajemen, (Jakarta: Kencana Prenadamedia Group, 2005), hlm. 8. 
tanda penduduk dan kartu keluarga, sehingga mengakibatkan adanya kesulitan dalam pengurusan pembuatan paspor jamaah. Selain itu, adanya calon jama'ah haji lanjut usia yang tidak memiliki dokumen pendukung seperti surat nikah, ijazah, dan akte kelahiran sebagai suatu syarat umtuk pendaftaran calon jama;ah haji sehingga diharuskan membuat dokumen pendukung tersebut, Sedangkan didalam proses pengurusan atau pembuatannya membutuhkan jamgka atau rentang waktu yang lama dan tidak bisa dipastikan waktu selesainya karena berhubungan langsung dengan instansi atau lembaga pemerintah yang lainnya.3

Secara umum pengertian manajemen adalah suatu ilmu dan perencanaan, pengorganisasian, pengarahan dan pengawasan terhadap usaha-usaha para anggota organisasi dan pemakaian sumber daya organisasi untuk tercapainya tujuan yang telah di tetapkan sebelumnya. Manajemen memiliki kegiatan untuk memimpin, mengatur, mengelola, mengendalikan, dan mengembangkan. Pengertian pelayanan dalam Kamus Besar Bahasa Indonesia adalah menolong menyediakan segala bentuk hal apa yang dibutuhkan orang lain seperti tamu atau pembeli. Sedangkan menurut para ahli, yaitu suatu pelayanan sebagai proses pemenuhan kebutuhan seseorang melaluikegiatan orang lain yang secara langsung diterima, dengan kata lain dapat dikatakan bahwa pelayanan yaitu tindakan yang dilaksanakan oleh seseorang atau kelompok, lebih dari satu orang, melalui sistem, prosedur atau tata cara, dan metode tertentu untuk mememnuhi kepentingan orang lain yang harus sesuai dengan hak ysng dimilikinya.4

\section{Metodologi}

Metode penelitian yang digunakan peneliti yaitu metode kualitatif. Penelitian kualitatif yaitu penelitian yang bersifat deskriptif dan cenderung menggunakan analisis. Proses dan

\footnotetext{
${ }^{3}$ Seksi Penyelenggara Haji dan Umroh, Arsip "Laporan Realisasi Pelaksanaan Kegiatan Oprasional Penyelenggaraan Ibadah Haji Kabupaten Jepara Tahun 1436 H/2015M, (Jepara: Kementerian Agama kabupaten Jepara, 2015), hlm. 2.

${ }^{4}$ https://kbbi.web.id/layan
} 
maknanya lebih ditonjolkan dalam penelitian kualitatif. Landasan teori tersebut dimanfaatkan sebagai pemandu agar fokus pada penelitian sesuai dengan fakta yang ada di lapangan.5 Menurut Maleong, Metode Kualitatif adalah suatu penelitian ilmiah yang bertujuan untuk memahami suatu fenomena dalam kontak sosil secara alami atau natural dengan mengedepankan proses interaksi komunikasi yang mendalam antara peneliti dengan fenomena yang diteliti pada saat itu. 6

Teknik penentuan informan yang digunakan purposive sampling yaitu salah satu teknik sampling non random sampling dimana peneliti sendirilah yang menentukan pengambilan sampel dengan cara yaitu menetapkan ciri-ciri khusus yang sesuai dengan tujuan penelitian sehingga diharapkan dapat menjawab permasalahan penelitian tersebut.7 Pada penelitian ini informan yang dibutuhkan meliputi pengelola bagian penyelenggaraan haji dan umroh dan staf penyelenggaraan haji dan umroh. Waktu penelitian ini dimulai pada tanggal 28 September - 5 Oktober dn lokasi penelitian berada di Kantor Kementerian Agama Kabupaten Mojokerto. Teknik pengumpulan data yang digunakan yaitu a) wawancara yaitu teknik pengumpulan data yang dilakukan dengan bertatap muka atau face to face dan tanya jawab langsung antara peneliti dengan narasumber. Seiring perkembangan teknologi, metode wawancara dapat pula dilakukan melalui mediamedia tertentu, misalnya telepon, e-mail, atau skype. Wawancara terbagi atas dua kategori, yakni wawancara terstruktur dan tidak terstruktur. b) Observasi adalah memperlihatkan dan mengikuti. Memperhatikan dan mengikuti dalam makna mengamati dengan

\footnotetext{
${ }^{5}$ Wikipedia diakses pada tanggal 10 oktober 2020 pukul 22.20 https://id.wikipedia.org/wiki/Penelitian_kualitatif.

${ }^{6}$ Metodologi Penelitian Kualitatif, Herdiansyah Haris (2010).

${ }^{7}$ Statistikan diakses pada tanggal 11 Oktober 2020 pukul 05.37 https://www.statistikian.com/2017/06/penjelasan-teknik-purposivesampling.htm|\#: : :text=Purposive\%20sampling\%20adalah\%20salah\%20sat u,diharapkan\%20dapat\%20menjawab\%20permasalahan\%20penelitian.
} 
teliti dan sistematis sasaran pelaku yang dituju. Cartwright mendefinisikan sebagai suatu proses melihat, mengamati, dan mencermati serta merekam perilaku secara sistematis untuk tujuan tertentu. Observasi ialah suatu kegiatan mencari data yang dapat digunakan untuk memberikan suatu kesimpulan atau diagnosa.8 c) Dokumentasi adalah melihat dan menganalisis dokumen-dokumen yang dibuat oleh subjek sendiri atau oleh orang lain tentang subjek tersebut. Studi dokumentasi adalah salah satu cara yang dapat dilakukan untuk mendapatkan gambaran dari sudut pandang subjek melalui suatu media tertulis dan dokumen lainnya yang ditulis atau dibuat langsung oleh subjek yang bersangkutan itu. 9

Teknik analisis data yang digunakan peneliti yaitu,. 1) mereduksi data yang termasuk bagian dari teknik analisis data kulaitatif. Reduksi data adalah suatu bentuk analisis yang menajamkan atau menegaskan, menggolongkan, mengarahkan, membuang yang tidak digunakan, dan mengorganisasi data dengan cara sedemikian rupa hingga terbentuklah kesimpulan-kesimpulan finalnya dapat ditarik dan diverifikasi. 2) penyajian data merupakan salah satu kegiatan dalam pembuatan laporan hasil penelitian yang telah dilakukan supaya data yang telah dikumpulkan menjadi satu dapat dipahami dengan mudah dan dianalisis sesuai dengan tujuan yang diinginkan oleh peneliti. 3) Penarikan kesimpulan adalah suatu usaha untuk mencari (menemukan) atau memahami makna/arti, kerapian, pola-pola, penjelasan,alur sebab akibat atau proposisi. Sebelum melakukan penarikan kesimpulan pertama harus dilakukannya reduksi data, penyajian data serta penarikan kesimpulan atau verifikasi dari kegiatan-kegiatan sebelumnya. 10Dengan demikian kesimpulan dalam penelitian kualitatif

\footnotetext{
${ }^{8}$ Haris Herdiasyah, Op. Cit., Metodologi Kualitatif Untuk Imu-IImu Sosial, hlm. 131

${ }^{9}$ Wikipedia, diakses pada tanggal 11 Oktober 2020, pukul 05.48, https://id.wikipedia.org/wiki/Dokumentasi

${ }^{10}$ Quipper com, diakses pada tanggal 11 oktober 2020, pukul 05.50, https://www.quipper.com/id/blog/tips-trick/school-life/teknik-analisisdata-pengertian-jenis-dan-tahapannya/
} 
dimungkinkan untuk dapat menjawab rumusan-rumusan masalah yang sudah dirumuskan sejak awal. Keabsahan data dalam penelitian ini dengan penggunakan triangulasi yaitu metode yang digunakan dalam penelitian kualitatif untuk memeriksa dan menetapkan validitas dengan menganalisa dari berbagai perspekti

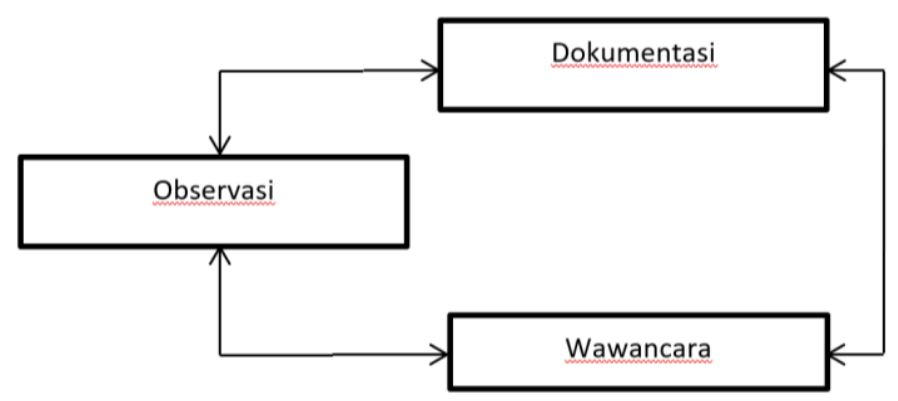

Triangulasi metode dilakukan dengan cara membandingkan informasi atau data yang diperoleh dengan cara yang berbeda.11 Dalam penelitian kualitatifini peneliti menggunakan metode wawancara, obervasi, dan survei. Untuk mendapatkan suatu kebenaran informasi yang handal dan gambaran yang sempurna mengenai informasi tertentu, peneliti juga dapat mengenakan metode wawancara dan obervasi atau pengamatan untuk mengecek kebenaran tersebut.lain dari itu, peneliti jugadapat menggunakan informan yang berbeda-beda untuk mengecek kebenaran informasi tersebut. Triangulasi tahap ini dilakukan jika data atau informasi yang didapatkan dari subjek atau informan penelitian diragukan kebenaran tersebut. Terdapat beberapa faktor untuk menentukan lokasi pada penelitian, yang dimana harus menjadi pertimbanga oleh seorang peneliti. Moleong berpendapat bahwa cara yabg

${ }^{11}$ Kompasiana com, diakses pada tanggal 11 oktober 2020, pukul 05.53, https://www.google.com/search?q=pengertian+triangulasi\&oq=pengertia n+triangulasi\&aqs=chrome..69i57j017.9921j0j4\&sourceid=chrome\&ie=UTF $\underline{-8}$ 
terbaik yitempuh dalam penentuan lapangan perlu sangat untuk penentuan lapangan suatu penelitian yaitu dengan jalan mempertimbangkan teori subsstantif. Geogrsfis penelitian dan kepraktikan penelitian seperti waktu, biaya, tenaga, perlu pula dijadikan pertimbangan dalam penentuan lokasi penelitian. Peneliti ini selanjutnya yaitu dengan membahas bagaimana manajemen pelayanan haji dan umroh di Kementerian Agama Kabupaten Mojokerto.

\section{Hasil dan Pembahasan}

Bagian pelayanan PHU di Kementerian Agama Mojokerto telah Melakukan tugas dan funngsi yaitu pelayanan dan bimbingan di bidang pendaftaran haji, pembinaan haji dan umrah, perjalanan dan dokumen, akomodasi dan pengelolaan keuangan haji, serta pengelolaan data dan informasi haji dan umrah. Hasil penelitian menunjukkan bahwa pelayanan yang diberikan oleh Kementerian Agama kabupaten Mojokerto kepada jamaah sudah baik. Hal ini terlihat dengan jenis pelayanan yang diberikan yaitu mulai dari pendaftaran, pemberangkatan, sertapemulangan jamaah haji. Untuk pelayanan kepada jamaah, Kementerian Agama kabupaten Mojokerto berusaha semaksimal mungkin menerapkan manajemen strategik. Hal ini terbukti dengan adanya prinsip-prinsip manajemen strategik yang dijalankan, seperti adanya perumusan strategi, implementasi strategi, dan evaluasi strategi untuk mencapai tujuan Kementerian Agama kabupaten Mojokerto.

Menurut A.s Moenir, yang dimaksut dengan manajemen pelyanan adalah manajemen proses, yaitu sisi manajemen yang mengatur dan mengendalikan proses layanan, agar mekanisme kegiatan pelayanan dapat berjalan tertib, lancar, tepat mengenai sasaran dan memuaskan bagi pihak yang harus dilayani, untuk dapat menyelenggarakan manajemen yang baik, ada prinsip-prinsip manajemen pelayanan yang dapat dipakai sebagai acuan.prinsipprinsip tersebut antara lain adalah sebagai berikut: 1) Mengidentifikasi kebutuhan jamaah, didalam PHU sesungguhnya, bahwasannya didalam Kementrian Agama Kabupaten Mojokerto telah mengidentifikasi kebutuhan jamaah dengan efisien, seperti 
adanya persyaratan persyaratan data diri sebelum mendapatkan atau mencetak porsi; 2) Menyediakan pelayanan yang terpadu, yaitu dengan adanya layanan atap sehingga memudahkan calon jamaah haji untuk menyelesaikan administrasi pendapatan porsi dengan itu akan terciptanya keefesienan waktu jadi jamaah tidak perlu mondar mandir lagi untuk ke luar Bank dikarenakan Kementrian Agama Kabbupaten Mojokerto telah menyediakan atau menerapkan layanan satu atap; 3) Adanya sistem dan mendukung pelayanan jamaah,yaitu dengan adanya sistem dari pemerintah sendiri yang bernama Siskohat yang digunakan Kemeterian Agama Republik Indonesia sebagai alat pendukung kerjanyademi keamanan data atau dokumen jamaah dari pemberangkatan samapai kepulangan dari tanah suci; 4) Mengusahakan agar semua orang atau karyawan bertanggung jawab terhadap kualitas pelayanan,didalam kantor semoa orang atau karyawan telah ditempatkan pada tugasnya masing-masing sesuai dengan bidang atau keahlian masing-masing sehingga apabila ada masalah yang mucul bisa diminimalisir; 5) Melayani keluhan jamaah secara baik,sudah diterapkan bahwa karyawan telah melayani segala permasalah yang dialami oleh calon jama"ah seperti kekeliruan nama dalam artian tidak sesuai antara di kartu keluarga (KK) dengan kartu tanda penduduk (KTP); 6) terus berinovasi,dengan adanya pergantian kepala kasi PHU pada tiap tahunnya pasti mempunyai inovasi yang terus berkembang, buktinya yaitu PHU Kabupaten Mojokerto lebih awal bisa dikatakan yang pertama menerapkan pengan adanya pergantian kepala kasi PHU pada tiap tahunnya pasti mempunyai inovasi yang terus berkembang, buktinya yaitu PHU Kabupaten Mojokerto lebih awal bisa dikatakan yang pertama menerapkan pelayanan satu atap pada 2016; 7) karyawan sama pentingnya dengan jama'ah,tidak ada penspesialan atau pembeda antara karyawan dan jamaah semua dianggap sama karena disitu terjadi hubungan interaksi yang dimana tujuannya sama; 8) bersikap tegas tapi ramah pada jam'ah, hal itu tentu sekali dilakukan pada karyawan PHU Kabupaten Mojokerto karena kenyamanan jamaah atau pendaftar adalah penting; 9) menjalin komunikasi dan interaksi khusus dengan 
jama'ah,dengan adanya konsultasi didalam PHU Kabupaten Mojokerto akan lebih nyaman dan mudah faham karena disitu dibuka setiap kali jamaah membutuhka atau mempunyai pertanyaan yang belum dimengerti; 10) Selalu mengontrol,tentu ada monitoring setiap kegiatan atau aktivitas yang berlangsung didalam PHU, apalagi sekarang adanya wabah virus Corona yang dimana diharuskan memakai masker dimanapun, disitu apabila ada yang tidak mengenakan dalam ruangan akan ditegor oleh kepala kasi PHU sendri.

Adapun ruang lingkup manajemen pelayanan haji dan umroh sebagaimana telah diatur dalam Undang-Undang Republik Indonesia ada 3, yaitu 1) Pembinaan; 2) Pelayanan; 3) perlindungan, disamping itu menurut bapak Mukti Ali, S.Ag, MM selaku Kepala Seksi PHU memgatakan bahwa kondisi real atau nyata ruang lingkup pelayanan haji dan umroh di Kementrian Agama Kabupaten Mojokerto senagai berikut:

\section{Pembinaan}

Pembinaan jamaah haji menjadi tanggung jawab pemerintah dan masyarakat seperti KBIH atau kelompok bimbingan agar bisa menjadikan jamaah yang mandiri (yang bisa menjalankan ibadah haji dengan mandiri tanpa ketergantungan ke lembaga) . untuk bimbingan manasik di KUA dilakukan 6 kali sebelum berangkat, di kemenag 2 kali berturut, di KBIH juga ada min 15 kali dalam setahun.Di kemenag kabupaten mojokerto ada progam bimbingan manasik sepanjang tahun sejak penetapan kuota sementara mulai bulan oktober sampai keberangkatan dengan bantuan KUA per kecamatan dan ormas yang ada, dan sudah berjalan selama 4 tahun.

\section{Pelayanan}

Pelayanan dokumen sebelum keberangkatan dirapikan dokumennya mulai dari dokumen pelunasan, paspor, lalu dokumen visa sampai berangkat dan pulang. Pelayanan perlengkapan haji seperti gelang identitas, koper, seragam, dll dari kemenag kerjasama dengan pihak lain (koper kerjasama dengan maskapai pesawat, seragam kerjasama dengan bank).

Pelayanan transportasi mulai dari keberangkatan sampai pulang (dari daerah ke embar kasih surabaya itu tanggung jawab 
pemerintah daerah, dari embar kasih ke bandara tangggung jawabnya maskapai sampai pulang, lalu di arab saudi tanggung jawabnya kedubes arab saudi). Pelayanan akomodasi mulai dari kesehatan, ibadah, umum

\section{Perlindungan}

Pemerintah memastikan jamaah haji aman, nyaman. Jika meningggal ada asuransi haji jika sakit akan menjadi tanggung jawab pemerintah. Disana ada petugas khusus untuk melindungi jamaah disebut "Linjam" yang bertugas apabila ada jamaah yang hilang, tersesat, meninggal akan menjadi tanggung jawab mereka untuk melindungi jamaah haji.Adapun kegiatan pelaksanaan pelayanan haji dan umroh di Kementerian Agama Mojokerto yaitu meliputi:

- Administrasi

Yaitu seluruh proses aktivitas yang dilaksanakan dan melibatkan seluruh orang secara bersama dalam organisasi untuk mencapai tujuan organisasi yang telah ditentukan. Berawal dari proses pendaftaran, pembayaran, dan surat keimigrasian, seperti pembuatan atau pncetakan porsi, pelimpahan porsi, pembatalan dan lain lain.

- Bimbingan Manasik

Yaitu ada 3 yang harus dilakukan saat bimbingan manasik 1) dinamakan pra haji yaitu supaya para rombongan jamaah mengerti dan faham bagaimana tata cara atau cara beribadah haji dan umroh yang benar ketika besok berada di tanah suci, 2) ketika berlangsung yaitu bimbingan yang dilakukan pada suci dengan cara pembimbing manasik bisa mendampingi , memberkan arahan pada jamaah, agar terlaksananya ibadah haji dan umroh yang kondusif ssuai tata cara ibadah haji yang sebenarnya, 3) tpaska haji atau sesudah haji bimbingan ini dilaksanakn sesudah pelaksanaan ibadah haji dan umroh untuk mempertahankan kemabruran ibadah haji dan umroh.

- Transportasi

Yang mana pergerakan calon jamaah haji dari asal daerahnya masing masing, dimana perjalanan yang dimulai, menuju ke Arab Saudi sampai kembali ke domisili masing masing, dan 
semuanya itu pasti memerlykan sarana transportasi yang sesuai dengan jarak tempuh perjalanan dan kapasitas kuota angkut.

- Akomodasi

Yaitu layanan yang diberikan secara maksimal terhadap jamaah haji seperti pelayanan penginapan dilengkapi dengan makan dan minumnya sekalian agar jamaah pada saat menjalankan ibadah haji menjadi khusyu'

- Konsumsi

Pemenuhan gizi atau penyajian makanan yang sudah terpenuhi segala standar gizinya guna jamaah merasa nyaman saat menjalankan ibadah haji dan umroh, disamping itu agar mereka mendapatkan kepuasan dari fasilitas yang sudah ada dan balance antara uang yang mereka keluarkan.

- Kesehatan

Pelayanan kesehatan seperti pemeriksaan, pemeliharaan kesehehatan calon jamaah haji, layanan ini dilakukan sebelum berangkat ke tanah suci seperti medical check up, suntikan vaxin miningitis, dan suntikan vaksin HINI agar pada saat jamaah melakukan ibadah haji tidak saling tular menular akan mengakibatkan ibadahnya terganggu dan tidak khusyu'

Adapun Perbedaan pelayanan haji dan umrohUmroh : jamaah harus mencari PPIU (Penyelenggara Perjalanan Ibadah Umroh) / travel lalu mendaftar ke travel tersebut lalu dibuatka SPPIU lalu dibawa ke kemenag kanwi; (SISKOPATUH) lalu nunggu keberangkatanHaji khusus SOP nya sama dengan umroh Tidak ada perbedaan SOP pelayanan haji dan umroh di kemenag yang lainnya, semua memakai SOP Nasional, kalau ada perbedaan mungkin dari segi inovasi seperti disini diadakannya layanan satu atap. Karena sejak tahun 2016 di kemenag kabupaten mojokerto mengawali dengan progam pelayanan satu pintu, maksudnya diadakanya kerjasama dengan pihak bank agar tidak perlu bolak balik ke bank untuk meminta validasi jadi sekali datang langsung dapat validasi dan mendapatkan porsi haji.

Didalam Kementerian Agama Kabupaten Mojokerto bagian PHU terdapat Standar Operasional Prosedur atau SOP yaitu proses dokumentasi yang dimiliki lembaga untuk memastikan bahwa 
layanan dan produk disampaikan secara konsisten setiap waktu.pada PHU keseluruhan mempunyai SOP masing-masing, dengan berjumlah 12 SOP, seperti SOP Pendaftaran dan SOP Pembatalan,

\section{Kesimpulan}

Bagian pelayanan PHU di Kementerian Agama Mojokerto telah Melakukan tugas dan funngsi yaitu pelayanan dan bimbingan di bidang pendaftaran haji, pembinaan haji dan umrah, perjalanan dan dokumen, akomodasi dan pengelolaan keuangan haji, serta pengelolaan data dan informasi haji dan umrah. Hasil penelitian menunjukkan bahwa pelayanan yang diberikan oleh Kementerian Agama kabupaten Mojokerto kepada jamaah sudah baik. Hal ini terlihat dengan jenis pelayanan yang diberikan yaitu mulai daripendaftaran, pemberangkatan, sertapemulangan jamaah haji. Untuk pelayanan kepada jamaah, Kementerian Agama kabupaten Mojokerto berusaha semaksimal mungkin menerapkan manajemen strategik. Hal ini terbukti dengan adanya prinsip-prinsip manajemen strategik yang dijalankan, seperti adanya perumusan strategi, implementasi strategi, dan evaluasi strategi untuk mencapai tujuan Kementerian Agama kabupaten Mojokerto.

Adapun ada prinsip-prinsip manajemen pelayanan yang dapat dipakai sebagai acuan.prinsip-prinsip tersebut antara lain adalah sebagai berikut: 1) Mengidentifikasi kebutuhan jamaah , 2) Menyediakan pelayanan yang terpadu, 3) Adanya sistem dan mendukung pelayanan jamaah, 4) Mengusahakan agar semua orang atau karyawan bertanggung jawab terhadap kualitas pelayanan, 5) Melayani keluhan jamaah secara baik,6) terus berinovasi, 7) karyawan sama pentingnya dengan jama'ah, 8) bersikap tegas tapi ramah pada jam'ah,9) menjalin komunikasi dan interaksi khusus dengan jama'ah,10) Selalu mengontrol.

Ruang lingkup manajemen pelayanan haji dan umroh sebagaimana telah diatur dalam Undang-undang Republik Indonesia ada 3 yaitu: 1) Pembinaan, 2) Pelayanan, 3) perlindungan. Kegiatan pelaksanaan pelayanan haji dan umroh di Kementerian 
Agama Mojokerto ada 5 yaitu meliputi: Administrasi, bimbingan manasik, transportasi, akomodasi, konsumsi, dan kesahatan.

Pelayanan Haji dan Umroh yang ada di Kementerian Agama Kabupaten Mojokerto memiliki fungsi untuk meningkatkan pelayanan dan penyelenggaraan ibadah haji dan umrah,jika mutu didalam pelayanan tersebut baik. Maka hasil yang didapatkan atau outcame otomatis baik begitupun dengan sebaliknya.

\section{References}

Ernie Tisnawati Sulekurniawa dan Kurniawan Saefullah, Pengantar Manajemen, (Jakarta: Kencana Prenadamedia Group, 2005), hlm. 8 .

Haris Herdiasyah, Op. Cit., Metodologi Kualitatif Untuk Imu-Ilmu Sosial, hlm. 131

https://kbbi.web.id/layan

Imam Syaukani (Ed.), Kepuasan Jemaah Haji Terhadap Kualitas Penyelenggaraan Ibadah Haji Tahun 1430 H/2009 M, (Jakarta: Puslitbang Kehidupan Keagamaan Badan Litbang dan Diklat Kementrian Agama RI, 2011), hlm. 1.

Kompasiana com, diakses pada tanggal 11 oktober 2020, pukul 05.53,

https://www.google.com/search?q=pengertian+triangulasi\&o $\mathrm{q}=$ pengertian+triangulasi\&aqs=chrome..69i57j017.9921j0j4\&so urceid $=$ chrome\&ie $=$ UTF-8

Metodologi Penelitian Kualitatif, Herdiansyah Haris (2010).

Quipper com, diakses pada tanggal 11 oktober 2020, pukul 05.50, https://www.quipper.com/id/blog/tips-trick/schoollife/teknik-analisis-data-pengertian-jenis-dan-tahapannya/

Statistikan diakses pada tanggal 11 Oktober 2020 pukul 05.37 https://www.statistikian.com/2017/06/penjelasan-teknikpurposivesampling.html\#: :text=Purposive \%20sampling\%20adalah\%20 
Mukti Ali, Nurul Wahidatul M, Wilis Ayu, Dea Fajar, Ni'matus Sholihah

salah\%20satu,diharapkan\%20dapat\%20menjawab\%20permas alahan\%20penelitian

Wikipedia diakses pada tanggal 10 oktober 2020 pukul 22.20 https://id.wikipedia.org/wiki/Penelitian_kualitatif.

Wikipedia, diakses pada tanggal 11 Oktober 2020, pukul 05.48, https://id.wikipedia.org/wiki/Dokumentasi 